\title{
PENGARUH BEBAN KERJA TERHADAP KINERJA KARYAWAN MELALUI BURNOUT SYNDROME PADA PT. PERKEBUNAN NUSANTARA X PABRIK GULA TJOEKIR
}

\author{
Ayuk Ainun Rahmadyah \\ Universitas Negeri Surabaya \\ Ayukrahmadyah@mhs.unesa.ac.id
}

\begin{abstract}
This study aims to determine and analyze the effect of mediation variable burnout syndrome between workload on employee performance in PT. Perkebunan Nusantara X Pabrik Gula Tjoekir. This research is a type of research with a quantitative approach, with a population of permanent employees in PT. Perkebunan Nusantara $X$ Pabrik Gula Tjoekir and the technique sampling with a sample saturated with a sample of 89 employees. The statistical analysis used in this study is Partial Least Square (PLS) analysis techniques and with software SmartPLS3. The statistical analysis tool in this study using the Partial Least Square (PLS) whit the software application SmartPLS3. The study results explained that workload has a positive and significant effect on employee performance, the workload has a positive and significant effect on burnout syndrome, burnout syndrome has a negative and significant effect on employee performance, and workload has no significant effect on employee performance through burnout syndrome. This study implies that if the company wants to improve employee performance, it must maintain environmental conditions, provide a portion of the work according to competence, control employee performance, and periodic job evaluation.
\end{abstract}

Keywords: burnout syndrome; employee performance; workload

\section{PENDAHULUAN}

Sumber daya manusia memiliki peran sebagai subjek pemangku kebijakan dan kegiatan organisasi perusahaan sekaligus merupakan aset perusahaan yang paling utama. Pemangku kepentingan perusahaan menyadari bahwa salah satu bagian dalam perusahaan yang mempunyai peran penting bagi kelangsungan perusahaan adalah sumber daya manusia, sehingga suatu organisasi perusahaan bergantung terhadap individu yang berada di dalamnya yang ikut ambil andil dalam kelangsungan kegiatan perusahaan (Priyono, 2010). Maka dari itu manajemen sumber daya manusia diharapkan dapat merencanakan, mengelola, serta mengendalikan sumber daya manusia dengan baik demi kelangsungan hidup organisasi atau perusahaan.

Kinerja karyawan diartikan sebagai sebuah pencapaian atau hasil kerja dari individu dalam menuntaskan tugas dan tanggung jawabnya yang mana suatu organisasi telah menetapkan sesuai dengan standar yang ada (Widyastuti, 2015). Sastra (2017) mengartikan kinerja (performance) sebagai refleksi seberapa produktif karyawsan dalam memenuhi persyaratan dari perusahaan dalam pencapaiannya menyelesaikan sebuah pekerjaan. Linda et al. (2014) menyatakan bahwa kinerja karyawan akan meningkat apabila adanya beban kerja yang semakin baik. Menurut Paramitadewi (2017), beban kerja merupakan sebuah proses menyelesaikan tugas pekerjaan dalam jangka waktu tertentu.

Harini et al. (2018) menunjukkan adanya pengaruh positif dan signifikan beban kerja (workload) terhadap kinerja. Sejalan dengan hasil penelitian Tjiabrata et al. (2017), beban kerja mempunyai pengaruh positif dan signifikan terhadap kinerja. Namun Paramitadewi (2017) menyatakan bahwa beban kerja mempunyai pengaruh negatif dan signifikan terhadap kinerja. Tidak seimbangnya beban kerja menyebabkan karyawan tidak dapat maksimal dalam meningkatkan kinerja. Di mana dalam penelitian tersebut ditemukan bahwa tingginya beban kerja sangat memengaruhi tingkat kinerja karyawan.

Keadaan yang disebabkan oleh tuntutan pekerjaan seperti beban kerja dan sumber daya pekerjaan yang terbatas menyebabkan burnout syndrome (Demerouti et al., 2001). Beban kerja yang terlalu 
Ayuk Ainun Rahmadyah, Pengaruh Beban Kerja terhadap Kinerja Karyawan melalui Burnout Syndrome pada PT. Perkebunan Nusantara X Pabrik Gula Tjoekir

tinggi merupakan salah satu faktor yang menyebabkan terjadinya kelelahan yang berdampak terhadap penurunan kinerja (Fan \& Smith, 2017). Ketidakseimbangan antara kapasitas kerja seseorang dan tugas yang harus dipenuhi menyebabkan burnout syndrome yang dapat menyebabkan kecelakaan kerja (Enache, 2013).

Burnout syndrome merupakan sindrom psikologis yang berasal dari rasa kelelahan fisik, mental, maupun emosional yang dapat membuat seorang terganggu hingga menyebabkan penurunan terhadap pencapaian prestasi pribadi (Nugroho et al., 2016). Burnout syndrome disebabkan dari adanya upaya untuk bertahan dari tekanan situasi dan keadaan yang diakibatkan oleh akumulasi stres (Galanakis et al., 2009). Hasil penelitian mengenai burnout syndrome terhadap kinerja karyawan dapat dilihat dari penelitian Nugroho et al. (2016), bahwa burnout syndrome memiliki pengaruh signifikan negatif terhadap kinerja karyawan. Hasil penelitian juga didukung oleh penelitian Priyantika (2018), menyatakan bahwa burnout syndrome memiliki pengaruh signifikan negatif terhadap kinerja karyawan. Penelitian dengan hasil berbeda mengenai burnout syndrome terhadap kinerja karyawan terdapat pada penelitian Hera et al. (2016) menunjukkan bahwa burnout syndrome berpengaruh signifikan positif terhadap kinerja karyawan.

Berdasarkan fenomena yang ada di PT. Perkebunan Nusantara X Pabrik Gula Tjoekir, di mana terdapat beberapa permasalahan yaitu kurangnya tenaga kerja sehingga tiap karyawan harus mengerjakan dua pekerjaan sekaligus yang bukan merupakan tanggung jawabnya pada masa produksi gula. Hal tersebut didukung dari hasil wawacara dengan salah satu pimpinan bagian SDM yang menyatakan bahwa perusahaan selama lima tahun terakhir telah melakukan pemangkasan tenaga kerja. Berdasarkan uraian di atas, maka tujuan penelitian ini adalah untuk mengetahui beban kerja berpengaruh terhadap kinerja karyawan melalui burnout syndrome. Penelitian dilakukan pada karyawan tetap PT. Perkebunan Nusantara X Pabrik Gula Tjoekir yang merupakan perusahaan milik negara yang bergerak di bidang agroindustri khususnya pembuatan gula kristal putih, berlokasi di Jl. Irian Jaya Jombang.

\section{KAJIAN PUSTAKA DAN PENGEMBANGAN HIPOTESIS}

\section{Beban Kerja}

Beban kerja menurut Paramitadewi (2017) merupakan sebuah proses menyelesaikan tugas pekerjaan dalam jangka waktu tertentu. Dalam menyelesaikan sebuah tugas pekerjaan, kapasitas dan kinerja individu sangat dibutuhkan yang mana dapat dilihat dari jumlah pekerjaan yang mesti dilakukan, batasan waktu dalam menyelesaikan tugas, serta pemikiran individu terhadap pekerjaannya (Romadhoni et al., 2015). Beban kerja dapat dikelompokkan menjadi tiga kualifikasi yaitu under capacity (beban kerja rendah), beban kerja standart, dan over capacity (beban kerja tinggi) (Sitepu, 2013). Untuk mengukur beban kerja indikator yang digunakan pada penelitian ini dari Omar et al. (2015) yaitu: tepat waktu, waktu jam kerja, bekerja saat libur kerja, cepat dalam bekerja, aktivitas terpengaruh karena beban kerja, bangun larut malam karena pekerjaan, pada akhir hari kerja tidak memiliki energi tersisa, memiliki sedikit tekanan waktu, sibuk dan susah fokus saat bekerja.

\section{Burnout Syndrome}

Menurut Maslach et al. (2001) burnout syndrome didefinisikan sebuah respon stres interpersonal yang berkelanjutan yang sangat berat dalam pekerjaannya yang mana disebut sebagai sindrom psikologis. Burnout syndrome merupakan sindrom psikologis yang berasal dari rasa kelelahan fisik, mental, maupun emosional yang dapat membuat seorang terganggu hingga menyebabkan sebuah penurunan terhadap pencapaian prestasi pribadi (Nugroho et al., 2016). Priyantika (2018) mengemukakan bahwa burnout syndrome merupakan keadaan kelelahan seorang karyawan yang terjadi karena adanya pengaruh dari pekerjaan dan dapat mengakibatkan perasaan kecewa dan kelelahan, sehingga memicu perasaan karyawan untuk keluar dari perusahaan. Burnout syndrome dan stres merupakan dua hal yang berbeda, akan tetapi adanya stres yang berlarut-larut dapat mengakibatkan terjadinya burnout syndrome. Untuk mengukur burnout syndrome indikator yang digunakan mengacu pada Herminingsih \& Kurniasih (2018) dan telah mendapatkan izin penggunaan indikator secara langsung melalui email. Adapun indikator dari Herminingsih \& Kurniasih (2018) yaitu: physical exhaustion (kelelahan fisik), 
depersonalization (depersonalisasi) dan personal accomplishment (rendahnya penghargaan terhadap diri sendiri).

\section{Kinerja Karyawan}

Menurut Mangkunegara (2013) kinerja merupakan suatu hasil kerja yang telah dihasilkan oleh individu karyawan baik secara kualitas maupun kuantitas dalam menjalankan suatu tugas yang diberikan kepadanya. Kinerja karyawan diartikan sebagai suatu pencapaian atau hasil kerja dari individu dalam menuntaskan tugas serta tanggung jawabnya yang mana suatu organisasi telah menetapkan sesuai dengan standart yang ada (Widyastuti, 2015). Sastra (2017) mengartikan kinerja (performance) sebagai refleksi seberapa produktif karyawan dalam memenuhi persyaratan dari perusahaan dalam pencapaiannya menyelesaikan sebuah pekerjaan. Untuk mengukur kinerja karyawan indikator yang digunakan pada penelitian ini dari Mathis \& Jackson (2006) yaitu: quantity of output (kuantitas dari hasil), quality of output (kualitas dari hasil), timeliness of output (ketepatan waktu dari hasil), presence of work (kehadiran), dan cooperativeness (kemampuan bekerjasama).

\section{Hubungan antar Variabel}

Diperlukan sejumlah standar beban kerja dan jumlah standar pekerja untuk satu bidang pekerjaan agar tidak terjadi beban kerja yang berlebihan (Dhelvia, 2018). Faktor penentu keberhasilan suatu perusahaan dapat dilihat dari kinerja karyawan. Untuk itu, sangat penting memerhatikan beban kerja agar tepat dan sesuai dengan kemampuan karyawan. Hal ini dikarenakan kinerja karyawan dapat dipengaruhi oleh adanya beban kerja sehingga berpengaruh juga terhadap pencapaian perusahaan (Chandra \& Adriansyah, 2017). Sitepu (2013) menyatakan setiap karyawan memiliki kinerja yang baik apabila didukung dengan adanya beban kerja yang tidak tinggi (over capacity) karena akan berpengaruh terhadap kondisi fisik dan psikis dari karyawan tersebut. Artinya, semakin baik penerapan beban kerja, maka akan semakin baik pula hasil kerja karyawan. Pengaruh beban kerja terhadap kinerja karyawan dibuktikan melalui penelitian Tjiabrata et al. (2017) pada 42 karyawan bagian administrasi PT. Sabar Ganda Manado, yang mengemukakan bahwa beban kerja memengaruhi kinerja karyawan secara signifikan positif. Penelitian tersebut diperkuat oleh Zhou et al. (2016) yang hasilnya adalah adanya pengaruh signifikan positif antara beban kerja terhadap kinerja karyawan. Beban kerja secara signifikan positif memengaruhi kinerja karyawan telah diteliti sebelumnya, diantaranya oleh Harini et al. (2018) Hera et al. (2016), Widyastuti (2015), dan Dhelvia (2018).

H1 : Beban kerja berpengaruh signifikan positif terhadap kinerja karyawan pada PT. Perkebunan Nusantara X Pabrik Gula Tjoekir.

Beban kerja, lingkungan yang tidak memadai serta masalah psikologis ataupun fisik menyebabkan burnout syndrome. Burnout syndrome merupakan kondisi kelelahan fisik dan mental yang dialami oleh karyawan (Romadhoni et al. 2015). Beban kerja memberikan tekanan dan desakan sehingga akan memicu kelelahan secara fisik dan psikis. Artinya, bahwa tuntutan pekerjaan dalam jangka waktu yang cukup lama dapat mengakibatkan karyawan mengalami burnout syndrome (Darma, 2018). Kusumaningrum et al. (2016) menjelaskan bahwa beban kerja memengaruhi burnout syndrome secara signifikan positif. Penelitian lainnya yang memperkuat teori ini adalah Ziaei et al. (2015), hasil pengujiannya menunjukkan bahwa beban kerja memberikan pengaruh signifikan positif terhadap burnout syndrome pada karyawan administrasi di Kermanshah University of Medical Sciences. Pembuktian mengenai signifikan positif beban kerja terhadap burnout syndrome telah dibuktikan melalui berbagai penelitian terdahulu, diantaranya yaitu penelitian Atmaja \& Suana (2019), Herminingsih \& Kurniasih (2018), Xiaoming et al. (2014) dan Sari (2015).

H2 : Beban kerja berpengaruh signifikan positif terhadap burnout syndrome pada PT. Perkebunan Nusantara X Pabrik Gula Tjoekir.

Burnout syndrome merupakan akibat dari stres kerja dan beban kerja yang paling umum sehingga menyebabkan menurunnya terhadap kinerja karyawan (Laeeque, 2014). Burnout syndrome memiliki pengaruh yang kuat terhadap kinerja karyawan. Artinya burnout syndrome yang tidak segera diatasi 
Ayuk Ainun Rahmadyah, Pengaruh Beban Kerja terhadap Kinerja Karyawan melalui Burnout Syndrome pada PT. Perkebunan Nusantara X Pabrik Gula Tjoekir

dapat menyebabkan kinerja karyawan terus mengalami kemunduran (Asi, 2013). Pengaruh burnout syndrome terhadap kinerja karyawan dibuktikan melalui penelitian Fajriani \& Septiari (2015) pada 709 karyawan dari 163 perusahaan manufaktur di Batam, yang mengemukakan bahwa burnout syndrome memengaruhi kinerja karyawan. Sebuah penelitian pada 58 karyawan PT PLN (Persero) Unit Induk Pembangunan VIII Surabaya oleh Nugroho et al. (2016) mengemukakan hal yang sama yaitu secara signifikan negatif burnout syndrome berpengaruh terhadap kinerja karyawan. Burnout syndrome secara signifikan negatif memengaruhi kinerja karyawan telah diteliti sebelumnya, diantaranya oleh Priyantika (2018) Asi (2013), Adnyswari \& Adnyani (2017) dan Aji \& Palupiningdyah (2016).

H3: Burnout syndrome berpengaruh signifikan negatif terhadap kinerja karyawan pada PT. Perkebunan Nusantara X Pabrik Gula Tjoekir.

Beban kerja berlebihan yang dimiliki karyawan dapat memicu burnout syndrome, di mana kondisi ini akan dapat menurunkan kinerja karyawan (Fajriani \& Septiari, 2015). Penelitian terdahulu yang telah dilakukan oleh Kusumaningrum et al. (2016) pada 57 karyawan tetap PT. Nusantara Medika Utama Rumah Sakit (jember Klinik) menyatakan bahwa burnout syndrome mampu menjadi variabel yang memediasi hubungan antara beban kerja terhadap kinerja karyawan. Hasil yang sama juga dilakukan oleh Fajriani \& Septiari (2015).

H4 : Burnout syndrome memediasi pengaruh positif beban kerja terhadap kinerja karyawan pada PT. Perkebunan Nusantara X Pabrik Gula Tjoekir.

\section{METODE PENELITIAN}

Penelitian ini merupakan penelitian kuantitatif dengan pendekatan kausalitas serta inferensial. Penelitian ini dilakukan di PT. Perkebunan Nusantara X Pabrik Gula Tjoekir yang beralamat di Jl. Irian Jaya, Jombang, Jawa Timur. Jumlah populasi dalam penelitian ini sebanyak 89 orang karyawan tetap, dan pengambilan sampel dilakukan secara keseluruhan. Akan tetapi data yang lengkap dan kembali hanya sebanyak 49 orang responden. Metode pengumpulan data yang digunakan dalam penelitian ini berupa observasi, wawancara dan kuesioner. Dalam penelitian ini menggunakan skala pengukuran Likert 1-5. Teknik analisis yang digunakan pada penelitian ini adalah Partial Least Square (PLS) yang menggunakan perangkat lunak komputer yaitu smart PLS3.

\section{HASIL DAN PEMBAHASAN}

\section{Karakteristik Responden}

Dari hasil pengumpulan data dan pengolahan yang telah dilakukan, karakteristik responden pada karyawan tetap PT. Perkebunan Nusantara X Pabrik Gula Tjoekir yaitu responden berjenis kelamin laki-laki $(83,7 \%)$, usia rata-rata $42-51$ tahun $(57,1 \%)$, selanjutnya responden mayoritas dengan pendidikan SMA (51\%), serta keseluruhan berstatus sudah menikah (100\%). Sebagian besar masa kerja responden antara 5-15 tahun (49\%).

\section{Convergent Validity}

Seluruh indikator dianggap valid jika memiliki nilai korelasi lebih dari 0,70. Tetapi, pada penelitian ini tahap awal jika nilai loading antara 0,50 hingga 0,60 dianggap cukup (Chin dalam Ghozali, 2014:39). Berdasarkan gambar 1. Tentang outer loading diketahui hasil outer loading setiap indikator valid atau sudah memenuhi kriteria karena di atas 0,50. 


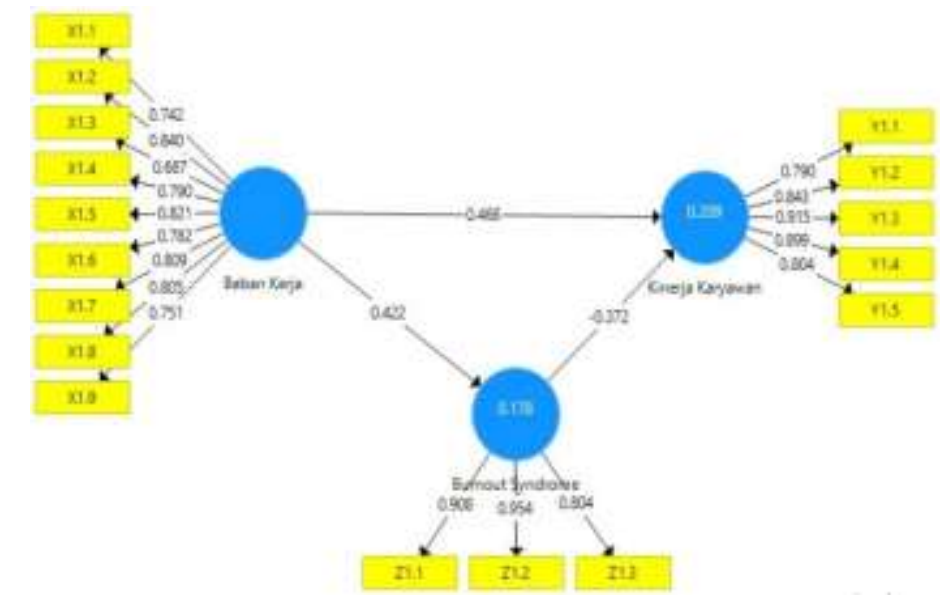

Sumber: Output SmartPLS3

Gambar 1. UJI MEASUREMENT MODEL

\section{Composite Reliability}

Composite reliability dikatakan baik apabila nilainya di atas 0,70 . Dari hasil pengujian untuk nilai composite reliability variabel beban kerja sebesar 0,934, variabel kinerja sebesar 0,929 , dan variabel burnout syndrome sebesar 0,920 . Nilai composite reliability pada masing-masing variabel lebih dari 0,70 , sehingga model telah memenuhi composite reliability atau memiliki reliabilitas yang baik.

\section{Croanbach's Alpha}

Croanbach's alpha mampu memperkuat hasil uji reliabilitas dari hasil composite reliability sebelumnya atau dapat dikatakan croanbach's alpha untuk mengevaluasi internal consistency. Dalam penelitian ini nilai croanbach's alpha variabel beban kerja sebesar 0,920, kinerja karyawan sebesar 0,905 dan burnout syndrome sebesar 0,871. Dengan demikian menunjukkan bahwa nilai croanbach's alpha untuk setiap konstruk model lebih dari 0,70. Maka model variabel tersebut telah memenuhi croanbach's alpha atau memiliki reliabel yang kuat.

\section{Analisis R-Square}

Berdasarkan hasil pengujian yang telah dilakukan menggunakan PLS dengan bantuan perangkat lunak smartPLS3, diperoleh nilai $R$-square yaitu:

\section{Tabel 1}

$R-S Q U A R E$

\begin{tabular}{cc}
\hline Variabel & R-Square \\
\hline Beban Kerja & \\
Burnout Syndrome & 0,178 \\
Kinerja Karyawan & 0,209 \\
\hline \multicolumn{2}{l}{ Sumber: Data diolah peneliti (2020) }
\end{tabular}

Berdasarkan tabel 1, dapat diketahui nilai $R$-square 0,178 menunjukkan bahwa pengaruh beban kerja terhadap burnout syndrome yaitu sebesar $17,8 \%$ dan untuk $82,2 \%$ dipengaruhi oleh faktor lain yang tidak terdapat di dalam penelitian ini. Nilai $R$-square 0,209 menunjukkan bahwa pengaruh beban kerja terhadap kinerja karyawan yaitu sebesar $20,9 \%$ dan $79,1 \%$ dipengaruhi oleh faktor lain yang tidak terdapat di dalam penelitian ini.

\section{Path Coefficients}

Tabel 2 menunjukkan hubungan antar konstruk dan nilai signifikan yang dapat dilihat pada uji kausalitas dengan estimasi koefisien jalur inner model. Berdasarkan tabel 2 diketahui bahwa besarnya 
Ayuk Ainun Rahmadyah, Pengaruh Beban Kerja terhadap Kinerja Karyawan melalui Burnout Syndrome pada PT. Perkebunan Nusantara X Pabrik Gula Tjoekir

nilai $t$-statistik pada pengaruh beban kerja terhadap kinerja karyawan adalah sebesar 2,460 >1,96. Hal ini menunjukkan adanya pengaruh yang signifikan pada variabel beban kerja terhadap kinerja karyawan, di mana beban kerja yang mampu meningkatkan kinerja karyawan.

Tabel 2.

PATH COEFFICIENTS

\begin{tabular}{ccccc}
\hline Pengaruh Antar variabel & $\begin{array}{c}\text { Original } \\
\text { Sampel }\end{array}$ & 'Statistik & Keterangan & Hasil \\
\hline Beban Kerja $\rightarrow$ Kinerja Karyawan & 0,466 & 2,460 & $>1,96$ & Hipotesis diterima \\
Beban Kerja $\rightarrow$ Burnout Syndrome & 0,422 & 3,588 & $>1,96$ & Hipotesis diterima \\
Burnout Syndrome $\rightarrow$ Kinerja Karyawan & $-0,372$ & 2,713 & $>1,96$ & Hipotesis diterima \\
\hline
\end{tabular}

Sumber: Data diolah peneliti (2020)

Berdasarkan tabel 2, besaran pengaruh beban kerja terhadap burnout sebesar 3,588 dilihat dari nilai tstatistik. Hal ini diartikan bahwa pada variabel beban kerja mempunyai pengaruh yang signifikan terhadap burnout syndrome. Di mana beban kerja yang dimiliki karyawan dapat meningkatkan burnout syndrome pada diri karyawan. Kemudian, pada tabel 2 di atas juga diketahui bahwa pengaruh burnout syndrome terhadap kinerja karyawan menunjukkan nilai $t$-statistik yaitu sebesar 2,713 . Hal ini menunjukkan variabel burnout syndrome mempunyai pengaruh yang signifikan terhadap kinerja karyawan.

Tabel 3.

HASIL INDIRRECT EFFECT

\begin{tabular}{ccccc}
\hline Pengaruh Antar Variabel & $\begin{array}{c}\text { Original } \\
\text { Sampel }\end{array}$ & $\begin{array}{c}\mathbf{T} \\
\text { Statistik }\end{array}$ & Keterangan & Hasil \\
\hline Beban Kerja $\rightarrow$ Kinerja Karyawan & 0,466 & 2,460 & $>1,96$ & $\begin{array}{c}\text { Hipotesis } \\
\text { diterima }\end{array}$ \\
$\begin{array}{c}\text { Beban Kerja } \rightarrow \text { Burnout Syndrome } \rightarrow \\
\text { Kinerja Karyawan }\end{array}$ & $-0,157$ & 1,569 & $<1,96$ & $\begin{array}{c}\text { Hipotesis } \\
\text { ditolak }\end{array}$ \\
\hline
\end{tabular}

Sumber: Diolah oleh peneliti (2020)

Pada tabel 3, diketahui bahwa besaran nilai koefisien pengaruh langsung antara beban kerja terhadap kinerja karyawan yaitu sebesar 0,466 dan nilai $t$-statistik 2,460 yaitu lebih besar dari 1,96 yang artinya signifikan. Adapun pengaruh tidak langsung beban kerja terhadap kinerja karyawan melalui burnout syndrome sebesar -0,157 dan nilai t-statistik 1,569 yaitu lebih kecil dari 1,96 yang artinya tidak signifikan. Hal ini menunjukkan bahwa variabel beban kerja berpengaruh secara langsung terhadap kinerja karyawan, tetapi tidak berpengaruh secara tidak langsung terhadap kinerja karyawan melalui burnout syndrome.

\section{Pengaruh Beban Kerja terhadap Kinerja Karyawan}

Hasil pengujian, menunjukkan bahwa beban kerja berpengaruh positif dan signifikan terhadap kinerja karyawan. Sehingga H1 diterima. Hasil dari penelitian ini didukung oleh Tjiabrata et al. (2017) dan Zhou et al. (2016), bahwa beban kerja berpengaruh secara positif dan signifikan terhadap kinerja karyawan. Dalam penelitian ini menunjukkan bahwa semakin besar tingkat beban maka akan terjadi peningkatan terhadap tingkat kinerja karyawan. Penelitian ini sejalan dengan penelitian lain yaitu diantaranya penelitian Harini et al. (2018), Hera et al. (2016), Widyastuti (2015) dan Dhelvia (2018).

Hasil analisis deskriptif variabel beban kerja mempunyai nilai rata-rata sebesar 2,63. Hal ini menunjukkan bawah beban kerja pada PT. Perkebunan Nusantara X Pabrik Gula Tjoekir termasuk dalam kategori sedang, sehingga beban kerja yang ada pada perusahaan termasuk dalam kualifikasi beban kerja standar. Sementara variabel kinerja karyawan mempunyai nilai rata-rata sebesar 3,97. Hal 
ini menunjukkan bahwa karyawan PT. Perkebunan Nusantara X Pabrik Gula Tjoekir memiliki kinerja yang tinggi dan baik dalam menuntaskan pekerjaannya.

Berdasarkan obervasi yang dilakukan pada karyawan PT. Perkebunan Nusantara X Pabrik Gula Tjoekir, tingkat beban kerja karyawan terbilang cukup tinggi. Salah satu faktorya yaitu dikarenakan saat masa produksi gula dilakukan sebanyak dua kali salama satu tahun. PT. Perkebunan Nusantara X Pabrik Gula Tjoekir terdiri dari enam devisi yaitu SDM, Keuangan \& Umum, Tanaman, Pengolahan, Instalasi dan QA (Quality Assurance) yang mana di setiap bagian pada masa produksi karyawan dituntut bekerja dengan cepat. Hal itu juga dapat dilihat dari hasil analisis deskriptif pada variabel beban kerja indikator bekerja dengan cepat mempunyai nilai rata-rata paling tinggi sebesar 3,08.

Pada bagian SDM sebelumnya hanya melakukan konseling, pengawasan terhadap pekerja, mengerjakan BPJS, serta administrasi penggajian hanya karyawan tetap tetapi pada masa produksi mereka harus mengurus seluruh karyawan baik karyawan tetap maupun karyawan dengan Perjanjian Kerja Waktu Tertentu (PKWT), sehingga menambah beban pekerjaan mereka. Pada bagian keuangan \& umum, karyawan harus melakukan administrasi sistem bagi hasil antara pabrik gula dengan petani selama masa produksi. Diketahui bahwa selama masa produksi di awal bulan dan pada pertengahan bulan terkadang karyawan mengalami pekerjaan yang menumpuk. Salah satunya adalah dikarenakan karyawan harus menyelesaikan pembayaran delivery order gula bagi petani dengan alat pencetak delivery order yang terbatas. Sementara itu karyawan harus mencetak 500 lembar di mana terkadang membuat karyawan mengalami lembur kerja serta membuat laporan PBHE (perhitungan bagi hasil efektif) antara pabrik gula dengan petani.

Pada bagian pengolahan, instalasi dan QA (Quality Assurance) beban pekerjaan yang cukup berpengaruh terhadap kinerja karyawan adalah kurangnya tenanga kerja. Sedangkan pada bagian ini memerlukan banyak tenaga kerja untuk pelaksanaan pengolahan produksi gula dan limbah, melakukan perawatan dan mengontrol setiap mesin yang beroperasi demi kelancaran proses produksi gula, serta memastikan bahwa kualitas gula setiap jamnya.

Akan tetapi hal tersebut tidak menyurutkan semangat karyawan maupun mengurangi tingkat kinerja. Karena karyawan menyadari sepenuhnya atas apa yang dikerjakan serta bertanggung jawab terhadap pekerjaan yang mereka terima. Selain itu apabila karyawan dapat memproduksi melebihi target yang telah ditentukan, karyawan akan mendapatkan insentif dari kantor pusat sesuai dengan tingkat jabatan.

Kinerja dalam penelitian ini dilihat dari kuantitas, kualitas, ketepatan waktu, kehadiran dan kemampuan bekerja sama. Kuantitas dan kualitas merupakan indikator yang paling berpengaruh, yang mana di perusahaan sendiri dapat terlihat jelas pada masa produksi di mana banyaknya pekerjaan serta dapat dilihat dari hasil gula yang dihasilkan, ketepatan waktu dari hasil dilihat pada karyawan yang tidak ada menunda-nunda pekerjaan, kehadiran dapat dilihat dari banyaknya karyawan tepat waktu pada saat masuk jam kerja, demikian kerja sama tim bisa terlihat pada masa produksi di mana karyawan saling membantu antar sesama. Dengan demikian tentu beban kerja dan kinerja karyawan di perusahaan menjadi meningkat dalam hal produksi gula pada masa produksi.

Hal ini menunjukkan bahwa karyawan mampu untuk mengatasi dan mengendalikan tuntutan beban pekerjaannya. Karyawan secara tidak langsung di tuntut dan memicu dirinya untuk dapat mengeluarkan kemampuannya secara maksimal karena adanya penerapan beban kerja di perusahaan. Dari analisis di atas dapat diketahui bahwa beban kerja (workload) mampu memengaruhi kinerja karyawan pada PT. Perkebunan Nusantara X Pabrik Gula Tjoekir. Hal ini membuktikan implementasi beban kerja dengan baik, kinerja karyawan juga dapat menjadi baik. Beban kerja dapat memberikan keterampilan, pengetahuan serta kemampuan seorang karyawan menjadi efektif.

\section{Pengaruh Beban Kerja terhadap Burnout Syndrome}

Dari hasil hipotesis, menunjukkan bahwa beban kerja berpengaruh positif dan signifikan terhadap burnout syndrome. Sehingga $\mathrm{H} 2$ diterima. Hasil penelitian ini mendukung penelitian terdahulu yang 
Ayuk Ainun Rahmadyah, Pengaruh Beban Kerja terhadap Kinerja Karyawan melalui Burnout Syndrome pada PT. Perkebunan Nusantara X Pabrik Gula Tjoekir

dilakukan oleh Kusumaningrum et al. (2016) dan Ziaei et. a.l (2015), bahwa beban kerja berpengaruh secara positif dan signifikan terhadap burnout syndrome. Dalam penelitian ini, peningkatan terhadap burnout syndrome dapat dipengaruhi oleh adanya beban kerja yang semakin melonjak. Penelitian ini sejalan dengan penelitian Atmaja \& Suana (2019), Herminingsih \& Kurniasih (2018), Xiaoming et al. (2014) dan Sari (2015).

Hasil analisis deskriptif pada variabel burnout syndrome menunjukkan bahwa indikator physical exhaustion dan personal accomplishment mempunyai nilai rata-rata yang sama sebesar 2,34. Hal ini menunjukkan bahwa karyawan PT. Perkebunan Nusantara X Pabrik Gula Tjoekir cenderung mengalami burnout syndrome dalam melakukan pekerjaannya.

Berdasarkan observasi yang dilakukan, tingkat beban kerja karyawan di perusahaan yang cukup tinggi adalah pada bagian produksi yaitu bagian pengolahan, instalasi dan QA (Qualiy Assurance). Hal tersebut dikarenakan saat masa produksi pada bagian ini merupakan bagian yang cukup krusial di perusahaan. Karyawan juga dituntut untuk menghasilkan gula sesuai dengan standart yang ada dan mencapai deadline yang sudah di tentukan oleh perusahaan. Pada bagian pengolahan, di stasiun masakan dan stasiun puteran, karyawan yang biasanya mengerjakan hanya satu alat tetapi pada masa produksi mereka mengerjakan dua atau lebih alat untuk mereka kontrol dan kendalikan. Pada bagian instalasi juga merasakan hal yang sama yaitu di stasiun gilingan dan stasiun puteran yang biasanya harus mengerjakan satu alat akan tetapi pada masa produksi mereka mengerjakan hingga dua atau lebih alat. Karyawan ada kalanya juga harus mengerjakan pekerjaan temannya apabila ada yang tidak masuk kerja. Sedangkan pada bagian QA (Quality Assurance), karyawan harus mengontrol kualitas gula per satu jam sekali untuk memastikan bahwa gula dalam kualitas yang bagus.

Beban pekerjaan yang diterima dapat menimbulkan perasaan tertekan sehingga karyawan tidak mampu bekerja dengan baik dan maksimal dikarenakan kurangnya tenaga kerja. Hal ini dapat menimbulkan sikap burnout syndrome pada diri karyawan dan secara tidak langsung dapat merugikan perusahaan (Atmaja \& Suana, 2019). Burnout syndrome dalam penelitian ini dilihat dari physical exhaustion (kelelahan fisik), depersonalization (sikap sinis mengenai karir dan kinerjanya sendiri), dan personal accomplishment (rendahnya penghargaan terhadap diri sendiri). Dari analisis di atas menunjukkan bahwa karyawan pada PT. Perkebunana Nusantara X Pabrik Gula Tjoekir mengarah kepada burnout syndrome secara physical exhaustion dan personal accomplishment. Hal ini terbukti dari karyawan yang sering mengalami kelelahan fisik di akhir hari kerja seperti sakit kepala dan nyeri punggung dikarenakan adanya keterbatasan tenaga kerja. Meningkatnya beban kerja yang dirasakan karyawan dapat mendorong terjadinya burnout syndrome.

\section{Pengaruh Burnout Syndrome terhadap Kinerja Karyawan}

Dari hasil hipotesis, menunjukkan bahwa burnout syndrome berpengaruh negatif dan signifikan terhadap kinerja karyawan. Sehingga H3 diterima. Hasil penelitian ini mendukung penelitian Fajriani \& Septiari (2015) dan Nugroho et al. (2016), bahwa burnout syndrome berpengaruh secara negatif dan signifikan. Hasil penelitian ini menunjukkan bahwa semakin rendah burnout syndrome maka semakin tinggi kinerja karyawan. Temuan tersebut sejalan dengan Priyantika (2018), Asi (2013), Adnyswari \& Adnyani (2017) dan Aji \& Palupiningdyah (2016). Indikator untuk mengukur burnout syndrome pada penelitian Nugroho et al. (2016) menggunakan Maslach \& Jackson (1981), sedangkan penelitian Asi (2013) menggunakan pengembangan dari Maslach et al. (2001) yaitu emotional exhaustion, depersonalizationi dan low personal accomplishment. Adapun penelitian Adnyswari \& Adnyani (2017) tidak disebutkan indikatornya. Dalam peneltian ini menggunakan indikator dari Herminingsih \& Kurniasih (2018) yaitu physical exhaustion, depersonalization dan personal accomplishment yang mana ruang lingkup indikator bukan hanya mengukur burnout syndrome secara emosional tetapi juga mengukur berdasarkan kelelahan fisik. Adapun kesamaan indikator dengan penelitian terdahulu yaitu depersonalization dan personal accomplishment karena dinilai lebih mengarah terhadap burnout syndrome secara umum.

Berdasarkan observasi yang dilakukan menunjukkan bahwa karyawan tidak merasakan burnout syndrome yang berkepanjangan karena memiliki kepercayaan dalam menyeimbangkan tuntutan 
pekerjaan dengan kemampuan atau tingkat kinerja. Karyawan menyadari dan merasa bahwa beban pekerjaan yang mereka terima merupakan sebuah tanggung jawab dari perusahaan yang harus diselesaikan. Dari hasil pengamatan penelitian pada karyawan di perusahaan, fakta di lapangan menunjukkan salah satu cara karyawan mengatasi burnout syndrome adalah dengan berinteraksi dengan rekan kerja. Adanya dukungan sesama rekan kerja, kerja tim yang baik, saling memotivasi sesama dapat menciptakan lingkungan kerja yang baik dan bersahabat sehingga membuat karyawan merasakan suasana yang menyenangkan serta menambah kepercayaan diri karyawan bahwa mereka mampu untuk menyelesaikan pekerjaannya.

\section{Pengaruh Beban Kerja terhadap Kinerja Karyawan melalui Burnout syndrome}

Dari hasil hipotesis, menunjukkan bahwa beban kerja dapat memengaruhi secara langsung terhadap kinerja karyawan tanpa melalui burnout syndrome. Sehingga $\mathrm{H} 4$ ditolak. Variabel burnout syndrome terbukti tidak mampu memediasi pengaruh beban kerja terhadap kinerja karyawan. Berdasarkan observasi yang dilakukan pada karyawan PT. Perkebunan Nusantara X Pabrik Gula Tjoekir, menunjukkan bahwa burnout syndrome yang dirasakan karyawan hanya pada saat masa produksi. Selain itu, menurut karyawan mereka merasa dapat mengatasi beban pekerjaan yang ada. Hal ini dapat terlihat dari cara karyawan bekerja dalam memenuhi target hasil gula tiap produksi dan dari kinerja karyawan yang tinggi. Burnout syndrome lebih berdampak terhadap karyawan yang bekerja pada bagian produksi seperti pada bagian Pengolahan, Instalasi dan QA (Quality Assurnace) karena mereka memiliki tuntutan pekerjaan yang lebih tinggi di masa produksi.

Hasil penelitian ini mendukung penelitian yang telah dilakukan oleh Kusumaningrum et al. (2016), bahwa beban kerja tidak berpengaruh signifikan terhadap kinerja karyawan dengan burnout syndrome sebagai variabel intervening. Penelitian tersebut mengungkapkan bahwa burnout syndrome yang dirasakan karyawan dipicu oleh beban kerja yang melebihi kemampuan.

\section{KESIMPULAN}

Beban kerja mempunyai pengaruh terhadap kinerja karyawan pada PT. Perkebunan Nusantara X Pabrik Gula Tjoekir secara signifikan positif. Beban kerja berpengaruh signifikan positif terhadap burnout syndrome. Burnout syndrome secara signifikan negatif berpengaruh terhadap kinerja karyawan. Beban kerja secara signifikan tidak berpengaruh terhadap kinerja karyawan melalui burnout syndrome pada PT. Perkebunan Nusantara X Pabrik Gula Tjoekir. Perusahaan perlu mempertahankan tingkat beban kerja yang ada dengan menjaga cara kerjanya serta menjaga kondisi lingkungan perusahaan sehingga membuat karyawan merasa nyaman dalam bekerja. Kinerja karyawan juga dapat dipertahankan oleh perusahaan dengan memberikan porsi pekerjaan kepada karyawan yang sesuai dengan kompetensi yang dimilikinya. Dengan adanya pemberian porsi pekerjaan dari perusahaan yang tepat kepada karyawan dapat meningkatkan dan memacu karyawan untuk semangat dan bekerja lebih baik. Selain itu menjaga bahwa burnout syndrome tidak memengaruhi kinerja dapat dilakukan dengan adanya pengontrolan secara rutin terhadap karyawan di perusahaan, mengatur waktu jam kerja karyawan yang mana sesuai dengan standart perusahaan, dan melakukan evaluasi kerja secara berkala.

Keterbatasan dalam penelitian ini adalah sedikitnya responden yang digunakan yakni 89 orang karyawan tetap PT. Perkebunan Nusantara X Pabrik Gula Tjoekir. Saran untuk penelitian selanjutnya yaitu menambah jumlah responden penelitian. Selain itu berdasarkan hasil wawancara di lapangan menunjukkan terdapat hal lain yang memengaruhi kinerja karyawan yaitu kepuasan karyawan terhadap hasil kerja. Sehingga diharapkan untuk penelitian selanjutnya dapat memertimbangkan variabel kepuasan kerja sebagai variabel dependen dalam penelitiannya.

\section{DAFTAR PUSTAKA}

Adnyswari, N. A., \& Adnyani, I. G. A. D. (2017). Pengaruh Dukungan Sosial Dan Burnout Terhadap Kinerja Perawat Rawat Inap RSUP Sanglah. E-Jurnal Manajemen Unud, 6(5), 2472-2500. 
Ayuk Ainun Rahmadyah, Pengaruh Beban Kerja terhadap Kinerja Karyawan melalui Burnout Syndrome pada PT. Perkebunan Nusantara X Pabrik Gula Tjoekir

Aji, M., \& Palupiningdyah. (2016). Pengaruh Servant Leadership Terhadap Kinerja Karyawan Dengan Burnout Sebagai Variabel Intervening. Management Analysis Journal, 5(3), 178-188.

Asi, S. P. (2013). Pengaruh Iklim Organisasi dan Burnout terhadap Kinerja Perawat RSUD dr. Doris Sylvanus Palangka Raya. Jurnal Aplikasi Manajemen, 11(3), 515-523.

Atmaja, I. G. I. W., \& Suana, I. W. (2019). Pengaruh Beban Kerja Terhadap Burnout Dengan Role Stress Sebagai Variabel Mediasi Pada Karyawan Rumours Restaurant. E-Jurnal Manajemen Unud, 8(2), 7775-7804.

Chandra, R., \& Adriansyah, D. (2017). Pengaruh Beban Kerja Dan Stres Kerja Terhadap Kinerja Karyawan Pada PT. Mega Auto Central Finance Cabang Di Langsa. Jurnal Manajemen Dan Keuangan, 6(1), 670-678.

Darma, W. (2018). Pengaruh Beban Kerja Dan Burnout (Kejenuhan Kerja) Terhadap Intensi Turnover Guru Sekolah Menengah Pertama Di Sekolah Bercirikan Agama Buddha Di DKI Jakarta. Jurnal Manajemen Pendidikan, 9(2), 131-140.

Demerouti, E., Nachreiner, F., Bakker, A. B., \& Schaufeli, W. B. (2001). The Job DemandsResources Model Of Burnout. Journal of Applied Psychology, 86(3), 499-512.

Dhelvia, R. (2018). The Influence Workload and Competence on Employee Performance in PT X Finance. Education and Humanities Research, 225, 135-138.

Enache, R. G. (2013). Burnout Syndrome and Work Accidents. Procedia - Social and Behavioral Sciences, (78), 170-174.

Fajriani, A., \& Septiari, D. (2015). Pengaruh Beban Pekerjaan Terhadap Kinerja Karyawan: Efek Mediasi Burnout. Jurnal Akuntansi, Ekonomi Dan Manajemen Bisnis, 3(1), 74-79.

Fan, J., \& Smith, A. P. (2017). The Impact of Workload and Fatigue on Performance. Centre for Occupational and Health Psychology, 726, 90-105.

Galanakis, M., Moraitou, M., Garivaldis, F. J., \& Stalikas, A. (2009). Factorial Structure and Psychometric Properties of the Maslach Burnout Inventory (MBI) in Greek Midwives. Europe's Journal of Psychology, 5(4), 52-70.

Ghozali, I. (2014). Structural Equation Modeling: Metode Alternatif Dengan Partial Least Squares $(P L S)$ (Keempat). Semarang: Universitas Diponegoro Semarang.

Harini, S., Sudarijati, \& Kartiwi, N. (2018). Workload , Work Environment and Employee Performance of Housekeeping. International Journal of Latest Engineering and Management Research (IJLEMR), 3(10), 15-22.

Hera, Rasyidin, \& Hasmin. (2016). Pengaruh Konflik Peran Ganda, Beban Kerja Dan Kelelahan Kerja (Burnout) Dengan Kinerja Perawat Wanita Di RSUD I Lagaligo Kabupaten Luwu Timur. Jurnal Mirai Management, 1(1), 119-135.

Herminingsih, A., \& Kurniasih, A. (2018). The Influence of Workload Perceptions and Human Resource Management Practices on Employees' Burnout (A Case Study on Mercu Buana University Administrative Staffs ). European Journal of Business and Management, 10(21), $19-26$.

Kusumaningrum, I. Y., Sunardi, \& Saleh, C. (2016). Pengaruh Beban Kerja Dan Karakteristik Individu Terhadap Kinerja Perawat Melalui Burnout Sebagai Variabel Intervening Pada PT. 
Nusantara Medika Utama Rumah Sakit Perkebunan (Jember KLINIK). Jurnal Bisnis Dan Manajemen, 10(3), 329-342.

Laeeque, S. H. (2014). Role of Work-Family Conflict in Job Burnout: Support from the Banking Sector of Pakistan. Internastional Letters of Social and Humanistic Scirnces, 40, 1-12.

Linda, M. R., Megawati, \& Japriska, Y. (2014). Analisis Pengaruh Beban Kerja, Lingkungan Kerja, Dan Motivasi Terhadap Kinerja Pegawai Badan Kepegawaian Daerah Kabupaten Pesisir Selatan Dengan Menggunakan Partial Least Square (PLS). Jurnal Manajemen Dan Bisnis, 3(1).

Mangkunegara, A. P. (2013). Manajemen Sumber Daya Manusia Perusahaan. Bandung: PT Remaja Rosdakarya.

Maslach, C., \& Jackson, S. E. (1981). The measurement of experienced burnout. Journal of Organizational Behavior, 2(2), 99-113.

Maslach, C., Schaufeli, W. B., \& Leiter, M. P. (2001). Job Burnout. Annual Review of Psychology, 52(1), 397-422.

Mathis, R. L., \& Jackson, J. H. (2006). Human Resource Management (Kesepuluh). Jakarta: Salemba Empat.

Nugroho, H. R., Susilo, H., \& Iqbal, M. (2016). Pengaruh Job Burnout Dan Kepuasan Kerja Malalui Komitmen Organisasional Terhadap Kinerja Karyawan (Studi Pada Karyawan PT. PLN (Persero) Unit Induk Pembangunan VIII Surabaya). Jurnal Administrasi Bisnis, 37(2), 173182.

Omar, M. K. (2015). Workload, Role Conflict and Work-Life Balance Among Employees of an Enforcement Agency in Malaysia. International Journal of Business, 8(2), 52-57.

Paramitadewi, K. F. (2017). Pengaruh Beban Kerja Dan Kompensasi Terhadap Kinerja Pegawai Sekretariat Pemerintah Daerah Kabupaten Tabanan. E-Jurnal Manajemen Unud, 6(6), 33703397.

Priyantika, D. F. (2018). Pengaruh Stres Kerja Terhadap Kinerja Karyawan Departemen Teknik PT. Pelindo Marine Service Surabaya Malalui Burnout Sebagai Variabel Intervening. Jurnal Ilmu Manajemen, 6(3), 296-305.

Priyono. (2010). Manajemen Sumber Daya Manusia (Kedua). Sidoarjo: Zifatama Publisher.

Romadhoni, L. C., Asmony, T., \& Suryatni, M. (2015). Pengaruh Beban Kerja, Lingkungan Kerja, dan Dukungan Sosial Terhadap Burnout Pustakawan Di Kota Mataram. Khizanah Al-Hikmah: Jurnal Ilmu Perpustakaan, Informasi, Dan Kearsipan, 3(2), 124-145.

Sari, N. L. P. D. Y. (2015). Hubungan Beban Kerja, Faktor Demografi, Locus Of Control Dan harga Diri Terhadap Burnout Syndrome Pada Perawat Pelaksana IRD RSUP Sanglah. COPING Ners Journal, 3(2), 51-60.

Sastra, B. A. (2017). Pengaruh Kompetensi Karyawan Dan Beban Kerja Terhadap Kinerja Karyawan Bank Danamon Cabanng Tuanku Tambusai Pekanbaru. Jurnal Online Mahasiswa Fakultas Ekonomi Universitas Riau, 4(1), 590-600.

Sitepu, A. T. (2013). Beban Kerja Dan Motivasi Pengaruhnya Terhadap Kinerja Karyawan Pada PT. Bank Tabungan Negara Tbk Cabang Manado. Jurnal Riset Ekonomi, Manajemen, Bisnis Dan Akuntansi, 1(4), 1123-1133. 
Ayuk Ainun Rahmadyah, Pengaruh Beban Kerja terhadap Kinerja Karyawan melalui Burnout Syndrome pada PT. Perkebunan Nusantara X Pabrik Gula Tjoekir

Tjiabrata, F. R., Lumanaw, B., \& Dotulong, L. O. H. (2017). Pengaruh Beban Kerja Dan Lingkungan Kerja Terhadap Kinerja Karyawan PT. Sabar Ganda Manado. Jurnal EMBA, 5(2), 1570-1580.

Widyastuti, N. (2015). Pengaruh Stres Kerja dan Beban Kerja terhadap Kinerja SKPD Kabupaten Sintang Kalimantan Barat. Jurnal Maksipreneur: Manajemen, Koperasi, Dan Entrepreneurship, 4(2), 15-27. https://doi.org/10.30588/jmp.v4i2.101

Xiaoming, Y., Ma, B., Chang, C. L., \& Shieh, C. (2014). Effects of Workload on Burnout and Turnover Intention of Medical Staff: A Study. 8(3), 229-237.

Zhou, H., Ye, L., \& Gong, D. (2016). Mental Workload's Influence on Job Performance for the High-Speed Railway Drivers - Job Satisfaction as Mediator. Services Technology and Management, 22, 287-300.

Ziaei, M., Yarmohammadi, H., Moradi, M., \& Khandan, M. (2015). Level of Workload and Its Relationship with Job Burnout among Administrative Staff. International Journal of Occupational Hygiene, 7(2), 53-60. 